Anthropos: Jurnal Antropologi Sosial dan Budaya (Journal of Social and Cultural Anthropology)

5 (2) (2020): 67-81, DOI: https://doi.org/10.24114/antro.v5i2.14114

Anthropos: Jurnal Antropologi Sosial dan Budaya (Journal

of Social and Cultural Anthropology)

Available online http://jurnal.unimed.ac.id/2012/index.php/anthropos

\title{
Global Interreligious Dialogue: Diplomasi Kultural dalam Kebijakan Dialog Agama Bilateral Indonesia
}

\section{Global Interreligious Dialogue: Cultural Diplomacy in Indonesia's Bilateral Religious Dialogue Policy}

\author{
Tyas Pramudita Indraning \\ Magister Sosiologi Agama, Universitas Kristen Satya Wacana, Indonesia
}

Diterima:19-07-2019; Disetujui:02-10-2019; Dipublish: 30-01-2020

\begin{abstract}
Abstrak
Tujuan penelitian ini, untuk menganalisis diplomasi kultural Indonesia melalui dialog agama antar negara. Secara spesifik penelitian ini dilatar belakangi dengan pemahaman diplomasi kultural Indonesia, dialog bilateral Lintas agama dan budaya dan diplomasi bilateral Indonesia. Diplomasi yaitu cara, dengan tata krama tertentu, yang digunakan suatu negara guna mencapai kepentingan nasional negara tersebut dalam hubungan dengan negara lain atau dengan masyarakat internasional. Dalam konteks dahulu efektifitas diplomasi memerlukan dukungan politik atau ekonomi atau kekuatan ekonomi, politik, militer yang rill, namun saat ini kita mengenal apa yang disebut diplomasi kebudayaan, yang justru kekuatan ekonomi, politik dan militer dalam hal-hal tertentu bersifat "counter productive". Dialog Bilateral adalah hubungan percakapan dua negara atau lebih dalam sebuah forum diskusi internasional untnuk meningkatkan hubungan kerja sama dalam bidang ekonomi, sosial, politik, budaya dan agama dalam rangka terciptanya kelangsungan hidup umat beragama di dunia yang rukun dan damai termasuk mengatasi berbagai isu global yang terindikasi mengancam keamanan dunia. Diplomasi kebudayaan merupakan bagian dari diplomasi publik (soft power diplomacy) dengan kerjasama ekonomi dan kebudayaan. Soft Power yaitu kemampuan mendapatkan apa yang dikehendaki dengan mengajak dan menarik simpati orang lain.
\end{abstract}

Kata Kunci: Dialog Agama, Diplomasi, Budaya, Bilateral agama

\begin{abstract}
This study analyse Indonesia's cultural diplomacy through inter-state religious dialogue. Specifically, this study aims to find out the background of Indonesian cultural diplomacy, bilateral dialogue between religions and cultures and Indonesian bilateral diplomacy. Diplomacy is a way, with certain manners, that is used by a country to achieve the country's national interests in relations with other countries or with the international community. In the context of the former effectiveness of diplomacy, it requires political or economic support or a real economic, political, and military power, but now we know what is called cultural diplomacy, which in fact economic, political and military forces in certain cases is "counter productive". Bilateral dialogue is a conversation between two countries or more in an international discussion forum to improve cooperative relations in the economic, social, political, cultural and religious fields in the framework of creating a harmonious and peaceful religious life in the world including overcoming various global issues indicated threatening world security. Cultural diplomacy is part of public diplomacy (soft power diplomacy) with economic and cultural cooperation. Soft Power is the ability to get what you want by inviting and attracting the sympathy of others.
\end{abstract}

Keywords: Dialogue on Religion, Diplomacy, Culture, Bilateral Religion

How to Cite: Indraning, T.P. (2020). Global Interreligious Dialogue: Diplomasi Kultural Dalam Kebijakan Dialog Agama Bilateral Indonesia. Anthropos: Jurnal Antropologi Sosial dan Budaya (Journal of Social and Cultural Anthropology) 5 (2): 67-81

*Corresponding author:

ISSN 2460-4585 (Print)

E-mail: tyaspramudita95@gmail.com

ISSN 2460-4593 (Online) 


\section{PENDAHULUAN}

Dunia saat ini diwarnai dengan berkembangnya Islamphobia, hatte speech (hoax). Meningkatnya intoleransi dan diskriminasi yang disebabkan oleh masalah ekonomi dan sosial seperti kemiskinan dan kurangnya pendidikan menjadi tanah yang subur bagi tumbuhnya id radikal. Hal ini dimanfaatkan oleh kelompok ektrimis untuk menggalang dukungan terutama dikalangan pemuda. Penulisan artikel ini akan mengkaji tentang diplomasi kultural dalam kebijakan dialog agama bilateral Indonesia.

Dialog antaragama diperlukan secara mutlak karena merupakan satu dari kebutuhan utama setiap agama untuk dapat menjadi dirinya. Dialog adalah cara bagaimana agama dapat mewujudkan dirinya sebagai satu kenyataan konkret dunia. Dialog dengan dunia berguna bagi duia sebagai pemeberi arah dan penjamin keteraturan seluruh proses (Kleden, 2002). Tanpa dialog dengan semua yang lain, termasuk agama-agama lain, satu agama tertentu akan kehilangan dinamikanya dan itu berarti kematiannya (Kleden, 2002). Hans Kung berpendapat "tidak ada perdamaian dunia tanpa perdamaian bangsa-bangsa, tidak ada perdamaian bangsa-bangsa tanpa perdamaian agama, dan tidak ada perdamaian agama-agama tanpa dialog lintas agama".

Melalui tulisan ini, argumentasi utama dan pemahaman mendasar penulis, bahwa dialog lintas agama sangat berkontribusi dalam menentukan perdamaian dunia, perlu diperkuat dengan melihat bahwa perdamaian antaragama menjadi syarat bagi suatu perdamaian dunia. Melalui forum dialog lintas agama paling tidak diharapkan akan melahirkan komunitas beradab, lembaga keagamaan bahkan bangsa-bangsa yang memiliki tanggung jawab moral untuk menjaga, merawat dan melestarikan perdamaian dunia. Setiap umat manusia pasti mempunyai visi tentang kehidupan bersama secara damai, tentang kebersamaan diantara berbagai kelompok agama dan wilayah yang berbeda (Kung, 1999). Semua agama mendambakan perdamaian dan keserasian hidup, sejak mulai dari kehidupan dalam kelompok pergaulan paling kecil keluarga, sampai kepada pergaulan antar-bangsa. Agamaagama itu mengajarkan cinta kasih, tolongmenolong, kedamaian dan nilai-nilai moral umat manusia (Warsito, 2007).

Selanjutnya dari kenyataan di atas, ketika berbicara relasi global, dibutuhkan instrumen pendukung untuk tercapainya apa yang diharapkan bersama; dan untuk tercapainya perdamaian dunia, forum- 
forum dialog lintas agama harus lebih sering diaktifkan dan dijalankan. Menurut Samuel Huntington dalam bukunya "clash of civilization" atau benturan antar peradaban, dunia di bagi atas tujuh peradaban. Peradaban Protestan, Khatolik di Amerika Selatan, Islam di Timur Tengah, Konghu Chu di China, Shinto di Jepang, Hindu di India dan Ortodoks di Eropa Timur (Azra, 2016). Terdapat mispersepsi dan misiinterpretasi terhadap Islam oleh dunia Barat bahwa ancaman terorisme telah mencitrakan Islam sebagai "sumber radikalisme" dan "pangkal aksi terorisme".

Nilai-nilai demokrasi dan Islam tidak dapat berdampingan secara damai dan harmonis. Berakhirnya perang dingin sumber konflik utama yang dihadapi umat manusia tidak lagi ideologi dan ekonomi, tetapi peradaban kebudayaan (Vitria, 2018). Bagi penulis kalau peradabanperadaban itu ditentukan oleh agama, maka agama betanggungjawab untuk menjaga perdamaian dialog supaya bisa menjaga perdamaian dunia ini. Disini penulis mau melihat bagaimana peran atau kontribusi Indonesia dalam diplomasi kebudayaan melalui dialog lintas agama yang dilakukan oleh Indonesia dengan beberapa negara sahabat di dunia internasional, untuk mempromosikan dan mendorong dialog lintas agama di kedua negara. Maka dilakukan program people to people contact dalam bidang sosial dan budaya. Bagi penulis pentingnya diplomasi kultural ini dilakukan menjadi salah satu untuk mempromosikan sikap saling menghargai dan membangun pemahaman yang sama diantara kedua masyarakat dan budaya.

Forum ASEM Interfaith Dialogue dapat mendorong diplomasi bilateral terkait interfaith dialogue dilakukan di Indonesia bersama negara-negara mitra ASEM lainnya secara konstruktif dan sustainable (Benarrivo, 2016). Forum ini dibentuk untuk memberi pemahaman terhadap publik tentang hubungan masyarakat internasional yang lebih damai dengan mereduksi gesekan akibat perbedaan keyakinan melaui cara-cara diplomasi" (Benarrivo, 2016). Selain itu ada juga kegiatan dialog lintas agama dan budaya yaitu MIKTA (Mexico, Indonesia, Korea Selatan, Turki dan Australia).

Kegiatan MIKTA InterfaithIntercultural Dialogue dibentuk untuk sebuah rangkaian inisiatif Indonesia untuk perlu berkolaborasi dengan antar negara guna menumbuhkan toleransi antar perbedaan dan menciptakan perdamaian. MIKTA perkuat kemitraan melalui lintas agama dan budaya, program MIKTA Interfaith-Intercultural Dialogue merupakan rangkaian Indonesia untuk perlu berkolaborasi dengan antarnegara 
guna menumbuhkan toleransi antar perbedaan dan menciptakan perdamaian.

\section{METODE PENELITIAN}

Dalam penelitian ini, jenis penelitian yang digunakan yaitu deskriptif dengan menggunakan metode penelitian kualitatif. Pendekatan-pendekatan kualitatif (Creswell, 2016). Jenis dan metode penelitian kualitatif digunakan untuk memperoleh data mendalam berdasarakan pada pemahaman-pemahaman para informan.

Data yang diperoleh akan diuraikan dengan kata-kata dan kemudian akan dianalisis secara ilmiah dengan kata-kata yang melatarbelakangi perilaku infoman terkait cara berpikir (Husaini \& Akbar, 2008).

Dengan demikian, metode ini akan mendeskripsikan dan menganalisis data dengan jelas berdasarkan temuan-temuan yang diperoleh dari para informan. Penelitian ini dilakukan di kantor Kementerian Luar Negeri, Indonesia. Dalam penelitian ini, teknik pengumpulan data yang digunakan, yaitu pertama, wawancara. Wawacara face to face dilakukan dengan tujuan untuk memperoleh data secara langsung dari tangan wawancara, dokumenter, foto-foto serta video dan pustaka.
HASIL DAN PEMBAHASAN

\section{Diplomasi Kultural Diplomacy)}

Diplomasi Publik

(Softpower

Diplomacy), diplomasi ini menekankan gagasan alternatif penyelesaian masalah pesan-pesan damai (Gabriella, 2013). Diplomasi kebudayaan (Cultural Diplomacy) dengan menanamkan, memelihara, dan mengembangkan citra bangsa Indonesia sebagai bangsa dan negara yang mempunyai banyak kebudayaan. Salah satu kebijakan Indonesia untuk melaksakan diplomasi kebudayaan dalam mengimplementasikan kebijakan politik luar negeri Indonesia. diplomasi kebudayaan Indonesia melalui politik luar negeri dilakukan untuk kepentingan nasional bangsa Indonesia, tujuan dan pencapaian pada keadilan sosial rakyat Indonesia. Dengan perkembangan dinamikaa hubungan internasional, kebijakan politik dan diplomasi tetap pada pelaksanaan yang bebas aktif. Prinsip bebas aktif memiliki citra yang positif karena mengedepankan independensi, berkawan dengan semua negara tanpa melihat idiologi, serta berusaha untuk aktif dalam mengatasi persoalan yang ada ditata hubungan internasional (Windiani, 2013)

Unsur kebudayaan yang dimiliki oleh Indonesia berupa festival angklung, tarian 
di berbagai daerah, pameran benda tradisional, pergelaran seni rupa, barangbarang antik, pertunjukan teater bahan baxar makanan tradisional dari berbagai daerah. Festival semacam inilah yang menarik minat sebagian besar massa dari negara-negara lain. Melalui festival tersebut, terjadi interaksi antar bangsa sebagai saranan diplomasi (Gabriella: 2013). Indonesia selain memiliki pesona alam uang indah, tetapi juga mempunyai keberagaman budaya yang berbeda yang dikenal dimata dunia, maka dilakukan diplomasi kebudayaan untuk menarik para wisatawan asing utnuk berkunjung ke Indonesia. Indonesia begitu banyak memberikan kontribusi pemikiran yang konkret untuk kemajuan keamanan dan kesejahteraan bagi perdamaian dan keamanan internasional. Kepentingankepentingan yang dimiliki Indonesia dengan negara-negara tetangga dikawasan lain yaitu untuk peningkatan hubungan sosial budaya.

Wujud diplomasi kebudayaan Indonesia dalam hal peran yaitu sebagai kepentingan nasional yang merupakan sebagai tantangan yang akan dihadapi Indonesia dalam melaksanakan misi diplomasi kebudayaan untuk bermitra pada salah satu negara maju dikancah Internasional. Diplomasi kebudayaan adalah bagian diplomasi publik (soft power diplomacy) dengan kerjasama ekonomi dan kebudayaan. Soft power yaitu suatu cara mendapatkan yang dikehendaki lewat mengajak dan menarik simpati orang lain. Diplomasi publik dalam bidang kebudayaan yang dilakukan oleh pemerintah Indonesia, dimungkinkan dapat memperluas wawasan publik melalui informasi yang diberikan, membangun citra Indonesia serta mengurangi mispersepsi bangsa lain terhadap Indonesia sehingga diharapkan dapat menciptakan suasana untuk mendukung kerja sama bilateral antarnegara.

Dalam pelaksanaan diplomasi kebudayaan, diperlukan aktor atau para pelaku. Diplomasi kebudayaan merupakan upaya untuk mencapai kepentingan bangsa dalam memahami, menginformasikan, membangun citra (mempengaruhi) bangsa lain lewat budaya. Diplomasi kebudayaan juga menjadi salah satu sarana yang untuk mencapai kepentingan negara, agar negara lain dapat memahami.

\section{Dialog Bilateral Lintas Agama dan Budaya.}

Bagi, bangsa Indonesia, Pancasila, dan UUD 1945 berisikan nilai-nilai dan norma-norma hukum yang telah disepakati bersama untuk dijadikan dasar 
dan sumber bersama bagi kehidupan berbangsa dan bernegara. Oleh sebab itu, etika politik bagi Indonesia harus mengacu pada dan tidak boleh bertentangan dengan nilai-nilai yang tercantum dalam Pancasila dan UUD 1945. Bagi Dukheim agama tidak dapat dipisahkan dari ide komunitass peribadatan atau moral (Durkheim, 2017). Terdapat banyak kesamaan pandangan mengenai nilai-nilai, prinsip, dan cita-cita politik diantara berbagai ajaran dan etika beragama. Sentimen keagamaan seringkali dikaitkan dengan nasionalisme reaktif dan kultural dalam mnentang kekuatankekuatan yang datang dari luar kontrol politik (Turner, 2012). Dengan kata lain, nilai-nilai, prinsip-prinsip, dan cita-cita yang sifatnya "universal" dalam arti melampaui batas tiap agama.

Agama adalah salah satu di antara berbagai institusi sosial lainnya yang dibutuhkan manusia. Aksi dan refleksi terjadi dalam hubungan-hubungan sosial antara sesama manusia yang menciptakan imajinasi sosial manusia, dan antara manusia dengan lingkungan sekitarnya (alam). Karenanya beragama tidak bisa dipisahkan dari berbudaya. Kebudayaan dirumuskan sebagai karsa, tindak cipta manusia yang terjadi dalam suatu lingkungan hidup tertentu (Titaley, 2013). Nilai-nilai yang dimaksud misalnya keadilan, perikemanusiaan, kesatuan, dan kesamaan dan martabat umat manusia, demokrasi. Kesamaan-kesamaan dalam nilai, prinsip dan cita-cita yang seharusnya secara intensif digali dan ditemukan bersama melalui dialog-dialog, untuk dicarikan rumusan implementasinya yang tepat, adil, dan dapat diterima oleh semua pihak (Sutarno, 2004). Forum dialog lintas agama tidak hanya menjadi ajang dialog, tetapi hasilnya dapat diimplementasikan keseluruh dikalangan.

Leonard Swidler (Lattu, 2016), guru studi dialog agama dunia, menjelaskan bahwa dialog adalah satu bentuk percakapan untuk mencari tujuan bersama masyarakat lintas agama. Dialog antaragama mempunyai fungsi kritis. Kalau kata "agama" dipahami secara konkret dan bukan secara metafisis, maka dialog antaragama berarti dialog antarorang yang beragama (Wahid, 2004). Dialog bilateral adalah hubungan dua negara atau lebih dalam forum diskusi internasional untuk meningkatkan hubungan kerjasama dalam bidang ekonomi, sosial, politik, agama dan budaya dalam rangka terciptanya kelangsungan hidup umat beragama di dunia yang rukun dan damai termasuk mengatasi berbagai isu global yang terindikasi mengancam keamanan dunia.

Dialog berbagai agama selaku himpunan sosial, bukan dalam arti 
perbandingan antara syahadat iman atau teologi-teologi yang berbeda, melainkan sebagai perjumpaan antar umat, masingmasing bertemu pada keyakinannya sendiri, tetapi terbuka bagi sesama dan bagi karya Roh, berdasarkan asal mula dan tujuan bersama sebagai sesama. Dialong dibangkitkan dengan merujuka pada kedamaian, aman dan terutama memastikan kepentingan nasional Indonesia. Pada tingkat bilateral, Indonesia menjalin persahabatan dengan seluruh negara di belahan dunia saat ini.

Agama-agama besar dunia sering kali memainkan peran utama dalam transformasi "peradaban", baik itu berlangsung sebelum ataukah bersamaan dengan globalisasi. Pada setiap kasus agama (khususnya, agama-agama dunia) selalu melampaui batas-batas kesatuan politik (Turner, 2013). Hubungan internasional yang sebelumnya didominasi dengan persoalan ideologi, ekonomi, politik, dengan kondisi dunia yang dianggap berada di era globalisasi, dalam isu yang sedang hangatnya demokrasi dan lintas agama, tentu akan lihat dari diplomasi kebudayaan (Cultural Diplomacy) yang dilakukan kerjasama antar negara untuk mencapai kepentingan nasionalnya. Indonesia terus berkomitmen untuk menciptakan dan memelihara perdamaian dunia dengan melalui dialog

lintas agama dan budaya dengan melibatkan negara-negara lain. Komitmen Indonesia dalam menciptakan perdamaian dunia tercermin dalam politik luar negeri.

Sebagai bagian dari kontribusi, Indonesia telah secara aktif melakukan beberapa inisiatif dalam mempromosikan dialog lintas agama dan antar budaya. Pada level Nasional kegiatan dialog lintas agama di Indonesia sebagian besar dimulai dan diselenggarakan oleh masyarakat sipil dan organisasi non-pemerintah yaitu: Nahdlatul Ulama, Muhammadiyah, Konferensi Uskup Katolik, Persekutuan Gereja-Gereja Indonesia, Dewan Buddhis Indonesia, Dewan Konfusianisme di Indonesia, Pusat Dialog dan Kerjasama antara Peradaban (CDCC), lembaga Wahid, dll. Indonesia memberdayakan kaum moderat dengan memprakarsai dan mendukung upaya dan kerjasama menciptakan dialog antar budaya dan agama antara masyarakat madani Indonesia dengan mitranya di luar negeri. Indonesia berupaya memperkuat dan memperluas forum-forum dialog antar agama/budaya serta meningkatkan kerjasama internasional yang lebih implementatif di tingkat akar rumput (Falahi, 2013). Indonesia mengambil peran sebagai bridge builder antara dunia Islam dan dunia Barat. 
Politik luar negeri adalah kondisi negara dan di pengaruhi oleh perubahanperubahan regional dan internasional. Selain level Nasional yang dilakukan oleh Indonesia, selanjutnya bentuk konkret nyata yang dilakukan sebagai bentuk kontribusi Indonesia dalam dialog lintas agama dan budaya yang ke-2 MIKTA. Kegiatan yang terselengara atas kerja sama Kementerian Luar Negeri dan Kementerian Agama Republik Indonesia. Agama perlu menjadi pemersatu untuk mengembangkan toleransi bukan untuk mecah. Dalam laporan pelaksanaan Strengthening MIKTA's Partnership: Interfaith-Intercultural Dialogues and Combatting Terrorism di Malang, 17-19 Oktober 2018. Pada pertemuan ini ini bertujuan untuk meningkatkan pemahaman lintas agama dan budaya antar negara MIKTA. Disamping itu, juga untuk menyatukan persepsi tentang pentingnya menjaga perdamaian, toleransi dan harmoni sosial, serta memperkuat kemitraan sesama MIKTA, termasuk penanganan kerja sama anti-terorisme dan deradikalisasi. Bahkan peranan oleh semua pihak baik pemerintah, pemuka agama, tokoh masyarakat maupun media massa akan sangat membantu untuk menciptakan nila-nilai yang harmonis dan toleransi serta perdamaian.

\section{Diplomasi Bilateral Pemerintahan}

\section{Indonesia Sebagai Perdamaian Dunia}

Dalam hubungan antarnegara, pada umumnya diplomasi dikencarkan pada tingkat paling awal sebuah negara yang hendak melakukan hubungan bilateral dengan negara lain hingga keduanya mengembangkan hubungan selanjutnya. Diplomasi bukanlah fenomena baru dalam sejarah manusia. Semanjak dunia mengenal hidup berkelompok dalam semacam sistem kenegaraan, berbagai primitif sistem, kita menemui kegiatankegiatan diplomasi dalam mengatur hubungan antara negara. Diplomasi sebagai manejemen hubungan antar negara dengan aktor-aktor hubungan internasional lainnya.

Diplomasi multilateral disebut confenrence diplomacy dan mempunyai ciri khas. Biasanya adalah suatu badan internasional (international institution) seperti PBB dan badan-badan lain atau pertemuan internasional. Dalam upaya peningkatan hubungan bilateral dilakukan dialog bilateral dari berbagai negara sahabat. Tentu dalam menjalankan hubungan bilateral dengan lebih 192 negara anggota PBB, Indonesia memiliki prioritas sesuatu dengan kepentingan nasional bangsa Indonesia. Pada tingkat global, Indonesia selalu menjadi bagian dari solusi (part of the solution) pada 
permasalahan global. Dalam hal ini, Indonesia menampilkan pendekatan dalam berbagai isu global krisis keuangan dan ekonomi, sosial, budaya, dialog antaragama, demokrasi, HAM dan kemanusiaan dan terorisme. Indonesia telah meningkatkan peran dan kontribusi dalam menyelesaikan berbagai permasalahan keamanan dan perdamaian dunia.

Kenyataan beragama sebagai bagian dari proses berbudaya dari manusia yang hidup dalam suatau batasan tertentu. Melihat secara khusus "berjumpa denga pemeluk agama lain adalah penting untuk melihat konteks bersama, Indonesia (Titaley, 2013). Untuk mencapai tujuan hubungan bilateral adalah dengan keraja sama bilateral dengan berbagai negara sahabat. Dengan slogan "milion friends, zero enemy" (Haryanto, 2011), Indonesia terus mengembangkan hubungan baik secara bilateral dengan seluruh negara di dunia dan tentu dengan prioritas kepentingan nasional Indonesia. Upaya peningkatan hubungan bilateral terus dilakukan dengan penekanan pada pembentukan mekanisme dialog bilateral dengan berbagai negara sahabat. Pada level Internasional, tahun 2014 Indonesia menjadi tuan rumah Forum Global ke-6 UNAOC di Kepulauan Dewata Bali dan secara aktif mengikuti Forum Global di
Baku Azerbaijan, April 2016. Tahun 2008, Indonesia memprakarsai Forum Demokrasi Bali untuk mengembangkan nilai-nilai demokrasi seperti partisipasi, inklusivitas, akuntabilitas dan transparansi untuk mendorong pembangunan ekonomi. Indonesia menyelenggarakan International Conference of Islamic Scholars (ICIS) di Malang, pada tanggal 23-25 November 2015, dan menjadi tuan rumah Seminar Internasional Hak Asasi Manusia Tetap Permanen (IPHRC) tentang Pendidikan Hak Asasi Manusia pada 12-13 Oktober 2015 di Jakarta. Serta beberapa program kegiatan MoU antar institusi pendidikan yang berkaitan dengan pertukaran mahasiswa (ex: Gontor dan Universitas Islam Rusia), pertukaran pengajar (ex: The Vienna International Christian-Islamic Summer University dengan UIN Sunan Kalijaga), kajian Imam, penelitian bersama, publikasi bersama, dan sertifikasi makanan halal.

Tujuan penguatan hubungan bilateral tersebut secara umum adalah menjaga integritas dan kedaulatan wilayah Indonesia; mendukung pembangunan ekonomi dan meningkatkan kesejahteraan nasional; melindungi warga negara Indonesia dan kepentingan Indonesia lainnya di luar negeri; serta mengembangkan kerja sama dalam penanganan isu-isu transnasional dan 
global. Untuk mencapai tujuan-tujuan tersebut, langkah yang diambil antara lain adalah penguatan mekanisme kerja sama bilateral dengan negara sahabat. Dalam upaya untuk mencapai kepentingan nasional, memenuhi kebutuhan dalam negeri, Indonesia melakukan hubungan diplomasi dengan negara lain. Hal tersebut untuk memenuhi kepentingan nasional, menurut Hans Morgenthau kepentingan nasional merupakan suatu negara untuk merebutkan kekuasaan yaitu apa saya dapat membentuk dan mempertahankan pengendalian suatu negara atas negara lain. Semua konflik internasional dianggap dapat diselesaikan dengan memuaskan, dan itu apakah melalui kompromi atau melalui arbitrase. Karena semua orang mengambil bagian dalam kemampuan berpikir, cepat atau lambat harus bertemu atas dasar yang sama, sambil mengetahui bahwa konflik mereka itu sungguh-sungguh dan dapat diselesaikna dengan rumus rasioanl yang dapat diterima oleh semua pihak.

Tujuan dari perumusan politik luar negeri untuk mempererat hubungan kerjasama dengan negara lain antara lain mengenai kelangsungan hidup bangsa dan negara, meningkatkan kesejahteraan ekonomi. Dan salah satu yang dilakukan pemerintah Indonesia dalam proses pencapaian kepentingan nasionalnya dengan melakukan diplomasi kebudayaan. Diplomasi kebudayaan merupakan soft power, pelaksaan politik dengan memanfaatkan hal-hal budaya, tanpa menggunakana kekerasan. Bahasa dan kesenian merupakan dua unsur budaya yang amata krusial dalam diplomasi kebudayaan, apalagi bahasa Indonesia telah dipelajari dibeberapa negara lain. Konsep soft power oleh Joseph S. Nye bahwa kekuasaan (power) pada dasarnya dapat dibedakan menjadi dua bagian, yaitu hard power dan soft power. Hard power adalah kontrol atas pikiran dan tingkah laku seseorang atas dasarnya mekanisme hukuman dan penghargaan. Soft power adalah kemampuan untuk mendapatkan apa yang diinginkan dengan cara membuat pihak lain tertarik sehingga keinginan pihak lain sejalan dengan keinginan kita tanpa melalui pemaksaan atau iming-iming imbalan.

Diplomasi kebudayaan harus dilakukan melalui publik sebagai satu upaya memperjuangkan kepentingan nasional melalui penyebaran informasi atau mempengaruhi pendapat umum yang dilakukan dengan memanfaatkan sarana budaya dan komunikasi. Diplomasi publik juga dapat menjadi jalan alternatif diplomasi berjalan lebih efektif dan memberikan dampak luas pada masyarakat internasional. Dalam 
menghadapi berbagai tantangan dan peluang di lingkungan global dan regional, politik luar negeri dan diplomasi Indonesia. Dilakukan untuk kepentingan nasional Indonesia tercapai. Diplomasi menjadi bagian dari upaya nasional untuk mencapai tujuan bangsa Indonesia. Politik luar negeri dan diplomasi menjadi suatu bagian untuk mendorong suatu pertumbuhan ekonomi dan kesejahteraan rakyat. Keterlibatan diplomasi publik dapat membuka jalan bagi negosiasi yang dilakukan wakil-wakil pemerintah, sekaligus dapat memberikan masukan dan cara pandang yang berbeda dalam memandang suatu masalah. Baik pemerintah maupun publik sepenuhnya memanfaatkan pengalaman dan sumber daya yangada dan bekerjasama untuk mempengaruhi nilai tawar pemerintah secara signifikan.

Diplomasi publik memungkinkan masyarakat, baik secara individu maupun dalam kelompok yang dibentuk pemerintah untuk berperan dalam memberikan masukan bagi kebijakankebijakan dalam dan luar negeri. Keberhasilan Indonesia sebagai penduduk muslim terbesar dalam melaksanakan pemilu demokratis menunjukkan kepada negara-negara Barat dan duniia internasional bahwa nilai-nilai demokrasi, Islam dan modernitas dapat berdampingan secara damai dan harmonis. Politik luar negeri Indonesia selanjutnya berupaya uuntuk membentuk sebuah forum regional mengenai demokrasi yang dapat berkontribusi pada pengembangan dan penguatan dialog, meningkatkan dan saling menghargai di antara bangsabangsa di Asia. Forum regional diharapkan dapat memperkuat institusi-institusi demokrasi dikawasan di Asia Pasifik melalui berbagai bentuk kerja sama internasional, diharapkan bisa berkontribusi pada penciptaan stabilitas dan perdamaian dunia.

Sebagai negara mayoritas muslim, Indonesia memandang untuk membangun dan meemperkuat dialog antar peradaban karena dipercaya dapat membantu menciptaakan dunia yang lebih aman dan damai, teruatama di tengah-tengah ancaman seperti terorisme. Dimata dunia, Indonesia di kenal sebagai negara yang sangat majemuk namun dapat hidup rukun dalam damai. Pada berbagai forum internasional, negara-negara sahabat telah meminta Indonesia membagikan pengalaman dalam mengelola kemajemukan tersebut. Karena kemajemukan harmonis telah menjadi aset yang sangat potensial bagi diplomasi publik Indonesia. Oleh sebab itu, sebagai bentuk upaya pro-aktif pemerintah dalam mengedepankan sikap toleransi, saling 
memahami dan menghargai antar sesama umat beragama dan antar peradaban demi terciptanya "harmony among civilizations", sejak tahun 2004 pemerintah Indonesia telah memanfaatkan aset kemajemukan tersebut dalam bentuk dialog lintas agama (DLA/Interfaith Dialogue) dan sejak saat itu dialog lintas agama menjadi fitur tetap diplomasi publik Indonesia baik pada tataran bilateral, regional maupun multilateral. DLA dibangun dan diperkuat karena dipercaya dapat memberikan kontribusi nyata dalam mengatasi tantangan internasional dewasa ini seperti masalah radikalisme dan terorisme.

Keberhasilan Indonesia sebagai negara berpenduduk Muslim terbesar dalam melaksanakan pemilu demokratis menunjukkan kepada negara-negara Barat dan dunia internasional bahwa nilai-nilai demokrasi dan Islam dapat berdampingan secara damai dan harmonis. Selanjutnya perlu dilakukan berbagai program dan kegiatan outreach kepada masyarakat baik di dalam maupun di luar negeri yang mengusung berbagai tema antara lain demokrasi; pemberdayaan kaum moderat; pengelolaan keberagaman budaya dan agama; serta toleransi kehidupan beragama yang seluruhnya dimaksudkan untuk mendukung arah kebijakan pemerintah Indonesia dalam mendorong tercapainya kerukunan antar peradaban.
Hingga saat ini, Indonesia telah memiliki 31 negara mitra DLA biateral dan juga menjadi promotor pada forum-forum DLA regional seperti Indonesia, Pasific dan MIKTA dan berpartisipasi aktif pada forum DLA multilateral seperti UNAOC. Pemerintahan Indonesia masih terus menerima permintaan dari negara-negara sahabat untuk bermitra dalam DLA. Pada level bilateral Indonesia telah melakukan dialog bilateral reguler dengan 31 negara dan berniat untuk memperluasnya, 31 negara dimaksud adalah: (Amerika Serikat Austria, Belanda, Inggris, Italia, Jerman, Meksiko, Pakistan, Polandia, Rusia, Vatikan, Kroasia, Singapura, MIKTA, Finlandia, India).

Tepat tanggal 17 Oktober 2018, Indonesia terpilih sebagai koordinator negara negara MIKTA yaitu Meksiko, Indonesia, Korea Selatan, Turki dan Australia. MIKTA telah melaksanakan berbagai kegiatan di bidang kontraterorisme, keamanan global, perdagangan dan ekonomi kreatif serta meningkatkan kapasitas pemeliharaan perdamaian. Sehubungan dengan hal tersebut, guna meningkatkan program kerjasama antar negara-negara MIKTA, Indonesia menyelenggarakan Dialog Lintas Agama dan Budaya yang kedua di Malang, Jawa Timur pada tanggal 17 s/d 19 Oktober 2018. Dialog Lintas Agama MIKTA 
2018 disinergikan dengan kegiatan InterCultural Dialogue, yang isinya membahas peran tokoh agama dan masyarakat lokal terhadap berbagai isu terkait toleransi antar umat beragama serta pemberdayaan generasi muda. Kegiatan Dialog Lintas Agama kali ini dilaksanakan selama tiga hari yang terbagi atas tiga sesi. Pertama yaitu, forum dialog, kedua public lecture dan ketiga site visit. Dialog Lintas Agama yang dihadiri oleh Cecep Herawan selaku Direktur Jenderal Informasi dan Diplomasi Publik, Kementrian Luar Negeri Republik Indonesia, bertujuan untuk mengeksplorasi kerjasama MIKTA terkait pemberatasan terorisme.

Dialog Lintas Agama kali ini selain dihadiri pejabat pemerintah, juga menghadirkan pembicara dari penasehat senior Presiden untuk Agama Internasional dan juga pemuka agama serta ilmuan dan intelektual. Mengelola keberagaman harus diawali dengan langkah berkomitmen dalam memajukan moderasi melalui dialog dan toleransi. Selain itu kearifan lokal dianggap paling efektif dalam menyelesaikan suatu konflik serta menciptakan perdamaian. Selain itu pada pertemuan MIKTA di Malang, semua peserta MIKTA mengapresiasikan inisiatif Indonesia untuk menyelenggarakan kembali kegiatan serupa. Hal ini mencerminkan bahwa Indonesia memiliki keberagaman agama dan budaya yang toleran sebaagi aset penting Indonesia dalam menjalankan soft diplomacy. Disamping itu, Indonsia memiliki pengalaman yang luas dalam menangani pelaku-pelaku teroris dan jejaringnya.

\section{SIMPULAN}

Diplomasi merupakan salah satu instrumen penting dalam pelaksanaan kepentingan nasional suatu negara. Diplomasi bagaikan alat utama dalam pencapaian kepentingan nasional yang berkaitan dengan negara lain atau organisasi internasional. Indonesia berkomitmen untuk menjadi penggerak utama dalam menebarkan nilai toleransi.

Indonesia memandang bahwa hak kebebasan beragama harus dijalankan secara bertanggung jawab dan menghormati hak asasi orang lain. Untuk itu, dalam menjalankan kebebasan beribadah dan menentukan agama atau kepercayaan seseorang serta kebebasan berekspresi dapat dimungkinkan dilakukan pembatasan berdasarkan hukum yang bertujuan untuk melindungi keamanan nasional, ketertiban, kesehatan, atau moral masyarakat atau hak-hak dan kebebasan mendasar orang lain.

Indonesia menolak dikaitkannya kegiatan terorisme dengan agama atau budaya tertentu. Indonesia sebagai bangsa 
yang majemuk memiliki kearifan dalam mengelola keberagaman dengan mengedepankan semangat dialog dan toleransi. Dialog Lintas Agama (DLA/Interfaith Dialogue) dijadikan salah satu fitur tetap dalam pelaksanaan politik luar negeri dan diplomasi Indonesia.Kebebasan berekspresi harus dihormati namun bukan tanpa batas. Kebebasan itu tidak boleh digunakan untuk membangkitkan kebencian, konflik dan perang. Nilai-nilai agama, kepercayaan dan kemanusiaan mutlak dihormati. Pemerintah Indonesia mengambil peran sebagai bridge builder dalam mengatasi the rise of identity politics berbasis atau memanfaatkan agama dan etnis, dengan merangkul berbagai organisasi keagamaan dan kemasyarakatan. Pemerintah Indonesia secara aktif mendorong sinergi antara demokrasi, agama, dan toleransi. Pendekatan top-down berupa peran aktif pemerintah menjadi kunci, seperti melalui good governance, supremasi hukum, dan penguatan demokrasi dari akar rumput (bottom up).

\section{UCAPAN TERIMAKASIH}

Terimakasih kepada donatur beasiswa Noto Hamidjojo, telah memberi biaya pendidikan kepada saya selama kuliah di UKSW.

\section{DAFTAR PUSTAKA}

Azra, A. (2016). Transformasi politik Islam, Radikalissme, Khalifalisme, dan Demokrasi, Jakarta: Prenadamedia Group.

Benarrivo, R. (2016). Diplomasi Indonesia dalam Membangun Interfaith Harmony melalui ASEM Interfaith Dialogue (2004-2009), Unjani: Jurnal Ilmu Hubungan Internasional, 1:(01), 117-132.

Benarrivo, R. (2016). Diplomasi Indonesia Dalam Membangun Interfaith Harmony Melalui Asem Interfaith Dialogue (2004-2009). Dinamika Global, Volume 01, No 01: 117132.

Creswell, J.W. (2016). Research Desaign: Pendekatan Metode Kuallitatif, Kuantitatif, dan Campuran, (Terjemahan) Yogyakarta: Pustaka Belajar.

Durkheim, E. (2017). The Elementary Forms of The Religious Life, (Terjemahan), Yogyakarta: IRCiSoD.

Falahi, Z. (2013). Signifikansi Diplomasi Islam Moderat Era Susilo Bambang Yudhoyono Dalam Merespon Problem Keamanan Timur Tengah, Andalas Journal of International studies (AJIS), 02: (1), 31-49.

Gabriella, C, (2013). Peran Diplomasi Kebudayaan Indonesia Dalam Pencapaian Kepentingan Nasionalnya. Makasar: Universitas Hasanudin.

Haryanto, A. (2011). Diplomasi Indonesia Hubungan Bilateral Internasional, Jakarta: Kementtrian Luar Negeri Republik Indonesia.

Husaini, U. \& Akbar Setiady Purnomo. (2008). Metodologi Penelitian Sosial. Jakarta: Bumi Aksara.

Jacob, T. (1994). Semangat Kecendekiaan Menggalang Perdamaian Dunia, Jakarta.

Keiser, B. (1991). Mewartakan Dalam Kebebasan: Gereja di Asia Dalam Dialog Dengan AgamaAgama Kebudayaan dan Kemiskinan. Yogyakarta: Kanisius.

Kleden, P. (2002). Dialog Antaragama Dalam Terang Filsafat Proses Alfred North Whitehead, Maumere: Ladalero.

Kung, H. \& Kuschel Joseph-Karl, (1999). A Global Ethic TheDeclaration of the Parliament of the World's Religions, (Terjemahan) Yogyakarta: Pustaka Pelajar.

Lattu, I, dkk, (2016). Sosiologi Agama: Pilihan Berteologi Di Indonesia, 25 Tahun Pascasarjana Sosiologi Agama Universitas Kristen Satya Wacana, Salatiga: Fakultas Teologi Universitas Kristen Satya Wacana.

Moleong, J.L, (2011). Metodologi Penelitian Kualitatif. Bandung: PT Remaja Rosdakarya. 
Partao, Z.A. (2007). Teknik Lobi dan Diplomasi Untuk Insan Public Relations. Depok: Perpustakaan Komnas Ham.

Stroyer, A. (2018). Sekretaris III Departemen Dipromasi Publik, Jakarta: Kementerian Luar Negeri Republik Indonesia.

Sutarno. (2004). Di Dalam Dunia, Tetapi Tidak Dari Dunia: Pemikiran Teologis Tentang Pergumulan Gereja Dalam Masyarakat Indonesia yang Majemuk, Jakarta: BPK Gunung-Mulia.

Titaley, J.A. (2013). Religiositas Di Alinea Tiga: Pluralisme, Nasionalisme dan Transformasi Agama-Agama, Salatiga: Satya Wacana University Press.

Turner, B.S. (2012). Relasi Agama dan Teori Sosial Kontemporer. (terjemahan), Yogyakarta: IRCiSoD.
Turner, B.S. (2013). Sosiologi Agama (terjemahan), Yogyakarta: Pustaka Belajar.

Vitria, V. (2009). Konflik Peradaban Samuel P. Huntington (Kebangkitan Islam yang Dirisaukan?). UNY: Jurnal Humanika, 9: (1), 39-52.

Wahid, A, dkk (2004). Dialog: Kritik dan Identitas Agama, Yogyakarta: Pustaka Pelajar.

Warsito, T, dan Kartikasari Wahyuni, (2007). Diplommasi Kebudayaan: Konsep Relevansi Bagi Negara Berkembang Studi Kasus Indoensia, Yogyakarta: Pustaka pelajar.

Windiani, R. (2013). Politik Luar Negeri Indonesia dan Globalisasi, UNDIP: Jurnal Ilmu Politik, 1: (2). 88-98. 